\title{
A Benchmark to Analyze On-Field Performances: A Case From an Irrigation Scheme in Tunisia
}

\author{
Salia Hanafi ${ }^{1}$, Hassouna Bahrouni ${ }^{1}$, Lassaad Albouchi ${ }^{2}$, Eymen Frija ${ }^{1} \&$ Jean-Cristophe Poussin ${ }^{3}$ \\ ${ }^{1}$ National Research Institute for Rural Engineering, Water and Forestry (INRGREF), University of \\ Carthage, Ariana, Tunisia \\ ${ }^{2}$ Higher School of Agriculture of Mograne (ESA-M), University of Carthage, Zaghouan, Tunisia \\ ${ }^{3}$ Research Institute for Sustainable Development (IRD), Montpellier, France \\ Correspondence: Salia Hanafi, National Research Institute for Rural Engineering, Water and Forestry \\ (INRGREF), University of Carthage, P.O. Box 10, Hedi Karray Street, PC 2080 Ariana, Tunisia. E-mail: \\ salia.hanafi@yahoo.fr
}

Received: January 19, 2021

Accepted: March 31, $2021 \quad$ Online Published: May 15, 2021

doi:10.5539/jas.v13n6p58

URL: https://doi.org/10.5539/jas.v13n6p58

\begin{abstract}
Irrigation systems entail interacting processes that should be considered when analyzing the performances of irrigated areas. When analyzing the cause of performance gaps, one may consider the effect of one factor without taking into account the effect of other influential ones. This study addresses the performance of irrigated areas using a global approach. The analysis includes different factors of the production process and examines the relationship between irrigation and the economic performances of farmers' irrigated fields. Results showed that technical efficiency (TE), considered as our economic indicator, evaluating the degree to which the inputs are used efficiently, was about 0.85 for fruit orchards, tomato, wheat and 0.66 for olive trees. The on-farm water distribution efficiency $\left(\mathrm{E}_{\text {farm }}\right)$ that evaluates water lost during its transport to plots was poor and can decrease to $36 \%$. A great potential for improving water management exists. $\mathrm{E}_{\text {farm }}$ was not a significant factor for TE. So, $\mathrm{E}_{\text {farm }}$ causing substantial water waste has no significant impact on economic performance, the main concern of the farmer. However the easy access to water was a significant factor for TE (p-value $<0.032$ in all the cases). The easy access to water is a possible lever for improvement. We pointed out that irrigation performance in the studied area has no significant impact on economic performance. There is a divergence between the farmer's interest (the economic efficiency) and the community's objective to save water through better irrigation performance. Government efforts to provide incentives for farmers for better water management seem to have born no fruit. This study argues for the use of a bechmarking in building global representation adapted to the actual local context. The analysis approch suggests that more attention should be paid to the "water saving program" of Tunisia, by subsidising irrigation investments in a better way and focusing on subsidies that create the most of economic growth.
\end{abstract}

Keywords: economic efficiency, bechmarking, irrigated fields, irrigation performance

\section{Introduction}

The evaluation of the irrigation performance is an essential activity to improve performance at plot, farm and scheme scale (Molden \& Sakthivadivel, 1999). Irrigation engineers have usually focused on a set of performance indicators related to application efficiency, on-farm distribution efficiency and uniformity of water distribution (Pereira, 1999; Horst, Shamutalov, Pereira, \& Gonçalves, 2005; Pereira, Dong, Mao, \& Fang, 2007; Juana, Rodriguez-Sinobas, Sànchez, \& Losada, 2007; Francis, Noble, Dennis, Rickerby, \& Knight, 2017), and sometimes extended to equity, flexibility, sustainability and productivity (Lorite, Mateo, \& Fereres, 2004; Gorantiwar \& Smout, 2005; Vandersypen, Bengaly, Keita, Sidibe, Raes, \& Jamin, 2006). Precise water use concepts and performance descriptors were proposed by Pereira, Cordery, and Iacovides (2011) in order to distinguish between water that can be reused and the actual lost water from a defined system by introducing the concepts of beneficial and non-beneficial water uses. These highly precise indicators take into account only variables and constraints related to irrigation activity, however, they do not consider economic and agronomic constraints affecting the performance of irrigated areas. Economists use the concept of efficiency to simply account for the criterion of maximal outputs and the possibility of minimal inputs. Agronomists have focused on 
the analysis of the soil-plant-atmosphere continuum. Several studies have focused on agronomic indicators based on Water Productivity (WP), which do not consider irrigation efficiency, or the water use efficiency (WUE) with more focus on irrigation efficiency (Pereira et al., 2011). These studies did not introduce in parallel the economic constraints for better irrigation performance. As presented above, irrigation engineers, economists and agronomists focused on performance indicators independantly. However, irrigation systems entail complex and interacting processes including physical, social, economic, political, technical and environmental dimensions (Le Grusse et al., 2009). Thus, there exists a gap that requires performance evaluation in-line with the inter-twined complex indicators. A split-up of domains is needed because a universal or single menu cannot be applied due to the diversity of issues (Malano, Burton, \& Makin, 2004; Zoebl, 2006). Thus, benchmarking identifies critical success factors of an organization to achieve its objective (Goodstein, Nolan, \& Pfeiffer, 1993). It is based on comparative indicators established when an irrigation system is more or less efficient than another and evaluating the gap between the current and the sought performances (Burt \& Styles, 2004).

In the Mediterranean basin, agriculture consumes more than $80 \%$ of the available water supplies (Capone, Bilali, Elferchichi, Lamaddalena, \& Lamberti, 2012). Despite the technical researches and technologies water losses stand over $50 \%$, and several studies show that irrigation performance at plot and farm scale remains unsatisfactory (Hamdi, Ragab, \& Scarascia-Mugnozza, 2003; Miao, Shi, Gonçalves, \& Pereira, 2015). Several technical and management problems remain unsolved in systems in many areas, along with a real danger of simply directing large investments into traditional public irrigation schemes (Merrey \& Sally, 2008). From this perspective, it seems that future research is still needed to analyse the low performance of the irrigation systems wich consists of a conveyance system, a distribution system and a field application system.

In Northern Tunisia, the irrigation schemes of the Medjerda Valley constitute a strategic lever. Studies on the performances of irrigation systems in these schemes were conducted by specialists who usually focused on single specific subjects (Zairi, El Amami, Slatni, Pereira, Rodrigues, \& Machado, 2003; Mailhol, Zairi, Slatni, Ben Nouna, \& El Amami, 2004; Yacoubi, Zayani, Zapata, Zairi, Slatni, Salvador, \& Palayan, 2010; Slatni, Zayani, Zairi, Yacoubi, Salvador, \& Playan, 2011). When analyzing the cause of some low performance, these studies may consider the effect of one factor without taking into account the effect of other influential ones. Moreover, the interaction of different factors amplifies the expected effect of a given constraint. Pereira, Oweis, and Zairi (2002) identified the need to develop appropriate methodologies to analyze social, economic and environmental benefits of improved irrigation management. Ghazouani, Marlet, Mekki, and Vidal (2009) have studied the farmers' discourse, practices and perceptions in the modernization program for a better management of an oasis in Southern Tunisia. Le Grusse, Mailhol, Bouaziz, Zairi, Raki, Chabaka, Djebara, and Ruelle (2009) have proposed an approach to simultaneously take into account the technical, agricultural, economic and environmental objectives at the farm level. Dirwai, Senzanje, and Mudhara (2019) proposed a method to assess causal factors of irrigation infrastructure without, however, remaining limited to hydraulic aspects. Rather, they introduced human, institutional and environmental factors.

The objective of the current study is to depict effective and pertinent factors explaining the field-level performances in view of a better management. It particularly aims to analyze the field level performances considering simultaniously irrigation and economic indicators, including different production factors, given our hypothesis that there is an interaction between these later indicators.

\section{Materials and Methods}

\subsection{Case Study}

The study area is an irrigation scheme located in the Medjerda Valley $\left(36^{\circ} 45^{\prime} \mathrm{N}, 9^{\circ} 45^{\prime} \mathrm{S}\right)$ and called "Borj Toumi" (Figure 1). This scheme is made up of 3 large farms of 100 ha each and 82 family farms of around 7 ha. The area was created by the Tunisian government in 1966 and covers 785 ha divided in two hydraulic sectors. A first one covers 425 ha and is supplied by a Gravity distribution System (GS). This system is made up of open-air pipes. A water bailiff opens the intake according to farmers demand. Farmers using under pressure irrigation techniques use their own pumping station. A second sector covers 360 ha and is supplied by a Pressurized distribution System (PS). Although water is supplied under pressure in this sector, farmers use surface irrigation on some fields. The water distribution system, which is buried, is built to serve farms on-demand, but secondary canals are not permanently filled. Some farmers are under the constraint of difficult access to water; some neighboring farmers take water from only one intake, some others at the end of the pipeline have a low pressure. In the other hand, mainly on the GS sector, farmers have an easy access to water. The easy or difficult access to water was a data given by the farmer. 


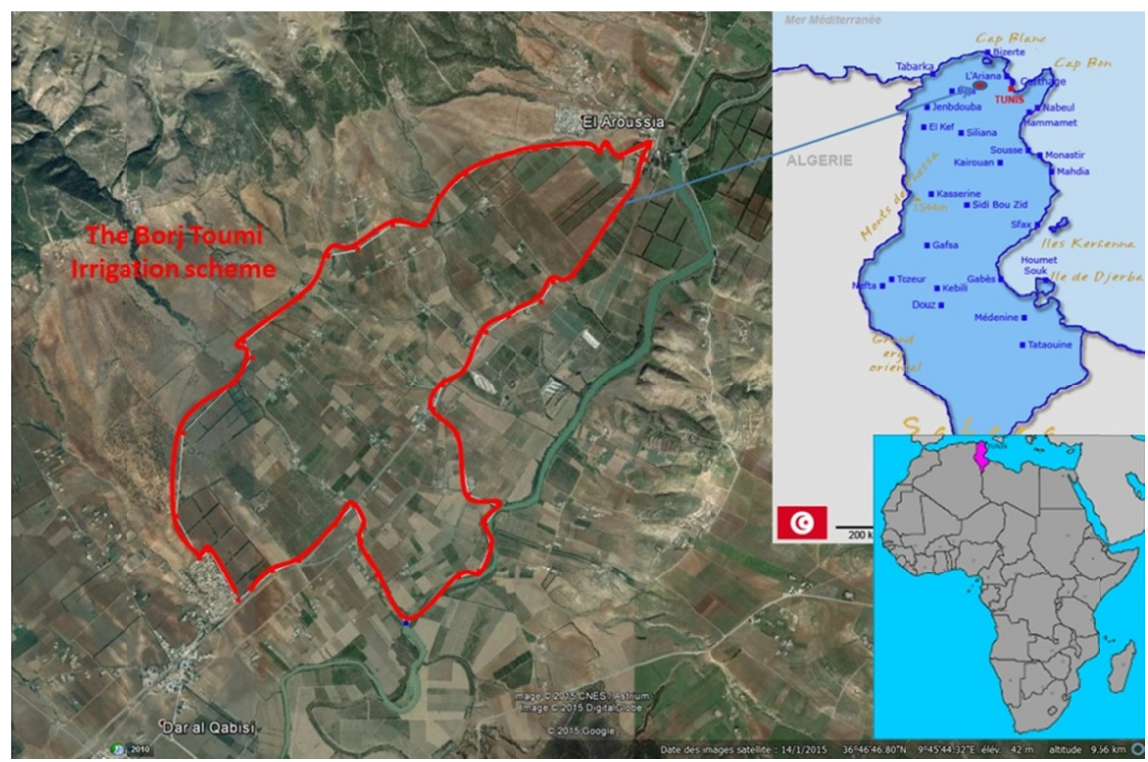

Figure 1. Satellite picture of the Borj Toumi irrigation scheme

\subsection{Surveys}

This study was conducted over three years, from 2015 to 2017. A first survey, done in 2015, was used to develop a typology, based on the area, crop diversity and irrigation techniques. The servey was adapted to the specificity of the scheme and was discussed with the development actors in-situ. The choice of farms and variables covered by this typology was not neutral. In fact, the 3 farms of disproportionate sizes (100 ha) compared to the average area of family farms ( $7 \mathrm{ha}$ ) were excluded to avoid analytical errors. The typology resulted in a classification of farms into 6 classes. As one of these classes is too small ( 4 farms), we considered only 5 classes in our analysis. Table 1 summurise the characteristics of each class. In class 1 , field crops were mainly irrigated by sprinkling. In class 2 and class 5 farms were similar in that they grew fruit trees; farms in class 2 introduced drip irrigation and were more intensive though. While in class 3 , farms had a high cropping intensification rate. In this class, with the smallest agricultural area, $67 \%$ of crops are intercropped. In class 4 , they had the most frequent use of drip irrigation. A second survey was conducted on 91 fields of 26 farms representing the five types from September 2016 to the end of August 2017. This second survey focused on yields, costs and selling prices of different practiced crops's production (olive trees, fruit orchard, tomato and wheat). Production costs were mainly machinery, seeds, labor, fertilizers, phytosanitary treatments and irrigation fees.

Table 1 Characteristics of the typical farm of the farmers' classes

\begin{tabular}{|c|c|c|c|c|c|c|c|c|c|c|}
\hline \multirow{2}{*}{ Class } & \multirow{2}{*}{ Area (ha) } & \multicolumn{2}{|c|}{ Farms Number } & \multicolumn{3}{|c|}{ Irrigation technique (\%) } & \multicolumn{4}{|c|}{ Area of crops grown (ha) } \\
\hline & & GS & PS & Surface & Sprinkler & Trickle & Olive & Tomato & Fruit & Wheat \\
\hline 1 & 7.64 & 15 & 7 & 24 & 55 & 21 & 1.77 & 1.12 & 0.42 & 2.87 \\
\hline 2 & 6.62 & 2 & 17 & 12 & 3 & 85 & 1.81 & 0.1 & 1.88 & 0.06 \\
\hline 3 & 5.25 & 0 & 15 & 63 & 3 & 34 & 4 & 3.94 & 0 & 0 \\
\hline 4 & 6.62 & 7 & 5 & 12 & 3 & 85 & 1.81 & 1.44 & 1.88 & 0.06 \\
\hline 5 & 6.05 & 1 & 7 & 48 & 16 & 36 & 2.93 & 2.08 & 0.61 & 0.95 \\
\hline
\end{tabular}

\subsection{Irrigation Performance}

Different irrigation performance indicators exist in literature. In this study, we were interested only in what is pertinent to the context of the studied scheme. As in situ heterogeneity of the yield has not been noticed, we were not interested in the uniformity indicators such as the application uniformity. Likewise, the application efficiency $\left(\mathrm{E}_{\mathrm{appl}}\right)$ indicates the importance of water losses below the root zone. For its estimation, soil samples moisture before and after irrigation events were done at 8 points on the diagonals of the irrigated plots. These measures showed that farmers had applied low water depths which had entirely been stored in the root zone. Therefore, the $\mathrm{E}_{\text {appl }}$ was not considered to be a pertinent irrigation indicator in this irrigation scheme. However, pipes 
transporting water from the farm entrance to the fields are worn out and are clearly the cause of water loss. So, we were interested in measuring how important the amount of lost water was between the farm entrance and that of the field. We consider this amount as lost because we are interested in consumptive and beneficial uses of the irrigation water cited in Pereira et al. (2011).

Particular points of water progress from the water reservoir to the field edge and the expression of efficiency in each section are shown in Figure 2. Water is first conveyed from the reservoir outlet to the farm gate. The efficiency of this step is termed conveyance efficiency $\left(\mathrm{E}_{\text {conv }}\right)$ and is calculated as the ratio of the water quantity diverted out of the reservoir $\left(\mathrm{W}_{\mathrm{vo}}\right)$ for that particular farm, to the quantity of water received at the farm gate $\left(\mathrm{W}_{\mathrm{fg}}\right)$. When it reaches the farm, water is distributed to the fields for irrigation. When it is at the field edge $\left(\mathrm{W}_{\mathrm{fe}}\right)$, it is applied as irrigation to the crop in the field. The efficiency of the on-farm distribution to the field is called farm efficiency $\left(\mathrm{E}_{\text {farm }}\right)$. It indicates the importance of the amount of water lost between the farm gate and the field edge. $\mathrm{W}_{\mathrm{fg}}$ is indicated by a water meter during the irrigation time. $\mathrm{W}_{\mathrm{fg}}$ is the billed quantity. $\mathrm{W}_{\mathrm{fe}}$ was calculated using the measured flow rate at field edge $\left(\mathrm{Q}_{\mathrm{fe}}\right)$ and the irrigation time $(\mathrm{T})$. We used ultrasonic flowmeter to measure the flow in the pipes with the pressurized irrigation techniques and a simple cut-throat flume to measure the flow in the gravity distribution canals in surface irrigation. Thirty-one $(\mathrm{n}=31)$ irrigation events were monitored. The 31 measurements of $\mathrm{E}_{\text {farm }}$ concern in fact the 91 fields because every distribution network is used for 2, 3 or 4 fields on the same farm. Results were qualified poor or good according to the Range of efficiencies described in Hsiao, Steduto, and Fereres (2007). $\mathrm{E}_{\text {farm }}$ is considered poor when it falls between 0.40 and 0.6 and good when it is between 0.65 and 0.95 .

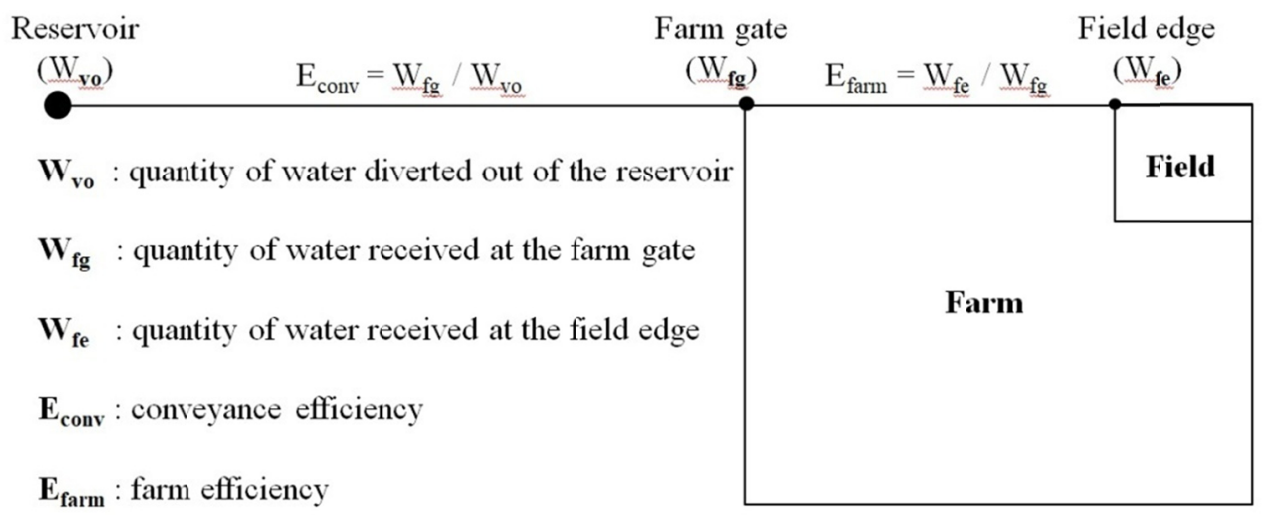

Figure 2. Water progress from the water reservoir to the field edge

\subsection{Management Performance}

In this study, the calculation was limited to the Technical Efficiency (TE) concept, which is a good proxy of farmers' management skills since all farmers buy their input from the same suppliers and sell their products for the same price. A producer's TE indicates how much they can increase outputs while using the same levels of inputs (output oriented). Figure 3 describes the TE calculation principle using DEA method.

Several mathematical techniques have been developed to compute the efficiency of a productive process. These techniques are called efficient-frontier techniques and comprise non-parametric techniques such as data envelopment analysis (DEA) and parametric techniques such as corrected ordinary least squares (COLS) and stochastic frontier analysis (SFA) (Bojanic, Caudil, \& Ford, 1998; Jamasb \& Pollitt, 2000; Sinuany-Stern, Mehrez, \& Hadad, 2000; Thanassoulis, 2000; Tongzon, 2001). The results from both methods are highly correlated in most cases (Wadud \& White, 2000; Thiam, Bravo-Ureta, \& Rivas, 2001; Alene \& Zeller, 2005), indicating that both methods are valuable.

In this study a non parametric technique introduced by Farrel (1957) was used. The non-parametric approach is based on the data envelopment method (DEA) which has a number of advantages such as; (Chemak, Boussemart, \& Jacquet, 2010). It simultaneously involves the following two steps:

Step 1: A number of observations about a set of fields are made. Each of these observation is compared to the others; a production frontier is represented by technically efficient fields; on this frontier, no field produces more with a lower quantity of inputs. Otherwise, it is included in the set of production 
possibilities and is declared to be of a certain technical inefficiency, hence its name of deterministic approach.

Step 2: It is the measurement of the difference between each of these fields and the production frontier which makes it possible to calculate the efficiency score of each field. The score values are between 0 and 1. This efficiency score will be lower if the representation of the farm is far from the production frontier.

Figure 3 describes the TE calculation principle using DEA method. This method uses piecewise linear programming to calculate the efficient frontier of a sample organization. Consider the following example: farmers $A$ and $B$ follow similar processes that use two inputs $\left(\mathrm{X}_{1}, \mathrm{X}_{2}\right)$ to poduce a given output $(\mathrm{Y})$. A and $\mathrm{B}$ are the most efficient farmers because they produce the most of output $\mathrm{Y}$ with the least of inputs $\mathrm{X}_{1}$ and $\mathrm{X}_{2}$. Farmer $\mathrm{C}$ is less efficient; distance to the efficient frontier (CC') measures its "inefficiency" and the ratio $\mathrm{OC}$ '/OC measures the TE of C. In this study, field-level TE scores are calculated using the DEAP program (Coelli, 1996) with one single output and two inputs. The considered farmers' output is the monetary production value of each field, while the inputs are the cultivated area of the field (in hectares) and the variable costs (in Tunisian Dinars "DT"; $1 \mathrm{DT}=2.45 €$ at the time of the survey). The output orientation option is chosen, consisting of exploring the scope of maximizing the output while using the same inputs. Given the fact that we are using monetary values as proxies of some of the inputs and outputs, the concept of TE in this study can also be interpreted as being reflective of the economic efficiency of the farmers (Bravo-Ureta \& Pinheiro, 1993).

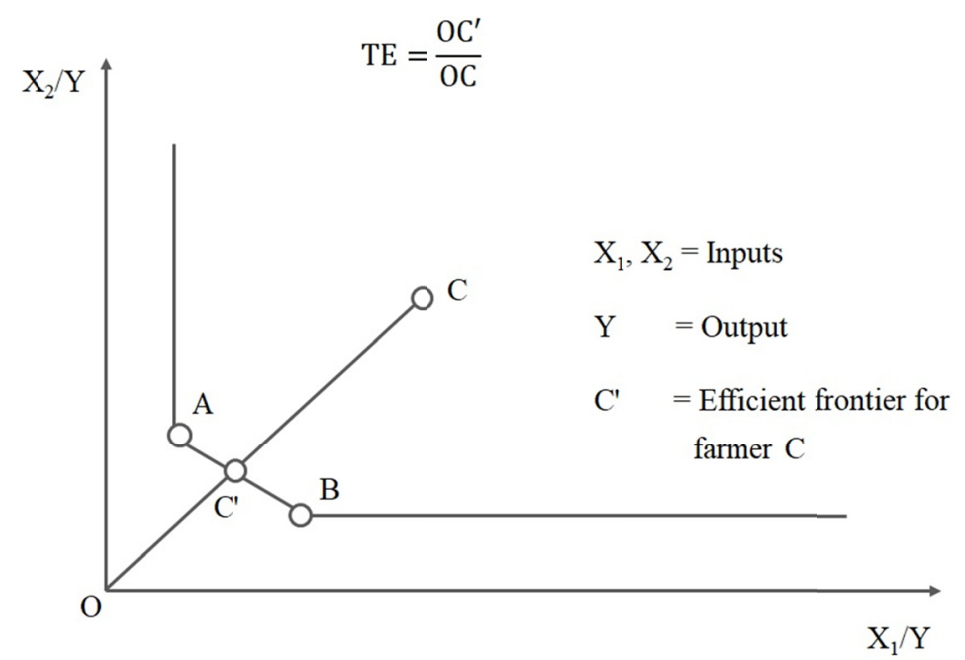

Figure 3. Principle of Technical Efficiency (TE) measure using DEA (Rodriguez-Diaz, Camacho, \& Lopez Luque, 2004)

Note. $\mathrm{Y}$ corresponds to the monetary production value of each field, however $\mathrm{X}_{1}$ and $\mathrm{X}_{2}$ correspond to the cultivated area of the field (in hectares) and the variable costs (in Tunisian Dinars), respectively.

\subsection{Statistical Analyses}

In this study, the one way ANOVA was performed using the SigmaStat software, from Systat Software, Inc., San Jose California USA, www.sigmaplot.com. The objective was to depict any possible correlation between economic and irrigation performances of the studied fields. The on farm irrigation diagnose conjugated to the perception of different stakeholds relative to this correletion let us retain a set factors for this analysis. These factors are the type of distribution sector (GS or PS), the irrigation technique (surface, sprinkler or trickle), and the farm efficiency $\mathrm{E}_{\text {farm}}$, in addition to the easy or difficult access to water. The appropriate comparison test is selected depending on the number of groups to compare and the distribution of the sample data. When comparing two groups, if samples are taken from normally distributed population and the variances are equal, the parametric unpaired t-test is used to compare the data samples directly. Otherwise, the Mann-Whitney rank sum test is used. The quantitative factors are transformed into classes which are aggregated when differences between the means (or the medians) are not significant. 


\section{Results}

\subsection{Irrigation Indicators}

Results of monitoring the irrigation events showed that the application efficiency was of $100 \%$ in all cases; soil-moisture samples before and after irrigation events showed that farmers applied low water depths which were stored entirely in the root zone; there was no water waste by percolation. There was nearly no water waste during the conveyance section. So, the $\mathrm{E}_{\mathrm{appl}}$ and the Econv were not considered as pertinent irrigation indicators in the context of the studied area.

In contrast, there was variability in the $\mathrm{E}_{\text {farm }}$. Results of measures of $\mathrm{E}_{\text {farm }}$ are summarized in Table 2. With surface irrigation technique, the $\mathrm{E}_{\text {farm }}$ vary between $36 \%$, on fields far from the farm gate and $100 \%$ on the fields near the farm gate with a mean value of $80 \%$. With under pressure irrigation technique,-the outdated equipment affected strongly the $\mathrm{E}_{\text {farm }}$ which ranged between $22 \%$ and $82 \%$ with a mean value of $59 \%$. Poor $\mathrm{E}_{\text {farm }}$ led to a great loss in water volumes destined for the crops. The on farm monitoring showed that the irrigation performances of some farms were dictated by the constraints of the public network. Obviously, the $\mathrm{E}_{\text {farm }}$ varied from one field to another depending on the availability of the flow and the pressure, the quality of the used equipment and on the farmer's skills. To these constraints relate to the section of the network between the farm gate and the edge of the field (Figure 2) are added the constraints relating to the conveyance section of the network, between the reservoir and the farm gate (Figure 2). As cited in Dirwai, Senzanje \& Mudhara (2019), the regulators in the conveyance canals showed signs of deterioration in the PS sector and also showed abuse and vandalism in the GS sector.

Table 2. Measurements of $\mathrm{E}_{\text {farm }}$ for fields with Surface and Pressurized irrigation techniques

\begin{tabular}{|c|c|c|c|c|c|}
\hline \multicolumn{3}{|c|}{ Fields with surface irrigation techniques } & \multicolumn{3}{|c|}{ Fields with pressurized irrigation techniques } \\
\hline Farm & Crop & $\mathrm{E}_{\text {farm }}(\%)$ & Farm & Crop & $\mathrm{E}_{\text {farm }}(\%)$ \\
\hline 1 & Olive trees & 65 & 14 & Wheat & 22 \\
\hline 2 & & 68 & 15 & & 50 \\
\hline 3 & & 72 & 16 & & 52 \\
\hline 4 & & 79 & 17 & & 54 \\
\hline 5 & & 90 & 18 & & 57 \\
\hline \multirow[t]{3}{*}{6} & & 100 & 19 & & 71 \\
\hline & & & 20 & & 73 \\
\hline & & & 21 & & 82 \\
\hline 7 & Fruit trees & 36 & 22 & Tomato & 48 \\
\hline 8 & & 63 & 23 & & 53 \\
\hline 9 & & 82 & 24 & & 54 \\
\hline 10 & & 88 & 25 & & 56 \\
\hline 11 & & 95 & 26 & & 56 \\
\hline 12 & & 100 & 27 & & 72 \\
\hline \multirow[t]{4}{*}{13} & & 100 & 28 & & 78 \\
\hline & & & 29 & Fruit trees & 51 \\
\hline & & & 30 & & 56 \\
\hline & & & 31 & & 81 \\
\hline Mean & & 80 & & & 59 \\
\hline Variat & nt (VC) & $24 \%$ & & & $25 \%$ \\
\hline
\end{tabular}

\subsection{Conventional Economic Indicators}

The entire tomato production in the study area is destined for manufacturing where farmers sell their production for the same standardized price. Similarly, the selling prices of olives and wheat are fixed by the government, so they do not display any variation among the sample farmers. As the study area is close to Tunis $(30 \mathrm{~km})$, most of the farmers sell their crops to the wholesale market for almost the same price. This indicates that the main difference in the farmers' income is due to their respective yields given that all the farmers buy their input from the same suppliers.

The results of descriptive statistics of economic data in relation to variable costs, gross margins and yields are summarized in Table 3. 
Table 3. Descriptive statistics of economic data related to crop surfaces (S), variable costs (VCo) and yields, (DT: Tunisian dinar, $1 \mathrm{DT}=2.45 €$ )

\begin{tabular}{|c|c|c|c|c|c|}
\hline Crop & & Mean & Median & Min & Max \\
\hline \multirow{3}{*}{ Olive } & S (ha) & 3.35 & 2.75 & 1.00 & 7.00 \\
\hline & VCo (DT/ha) & 478 & 432 & 237 & 807 \\
\hline & Yield (Kg/ha) & 2604 & 2390 & 750 & 6000 \\
\hline \multirow{3}{*}{ Fruit } & $\mathrm{S}(\mathrm{ha})$ & 1.41 & 1.38 & 0.25 & 2.5 \\
\hline & VCo (DT/ha) & 2121 & 1649 & 642 & 5767 \\
\hline & Yield (Kg/ha) & 5905 & 5000 & 3000 & 18000 \\
\hline \multirow{3}{*}{ Tomato } & S (ha) & 1.58 & 1.75 & 1.00 & 2.00 \\
\hline & VCo (DT/ha) & 3426 & 3368 & 2556 & 4042 \\
\hline & Yield (Kg/ha) & 69080 & 72500 & 36000 & 95000 \\
\hline \multirow{3}{*}{ Wheat } & $\mathrm{S}(\mathrm{ha})$ & 2.35 & 2.00 & 1.00 & 6.00 \\
\hline & VCo (DT/ha) & 454 & 433 & 31 & 958 \\
\hline & Yield (Kg/ha) & 2649 & 2500 & 1500 & 4000 \\
\hline
\end{tabular}

\subsection{Technical Efficiency Scores}

Calculations using the DEAP program provided technical TE scores for each field. Basic statistics for these efficiency scores are reported in Table 4. The mean values of TE for fruit trees, tomato and wheat showed that the average efficiency level of considered fields is high (around 0.85). Fields of olive trees were still producing at a lower efficiency level (average of 0.66 ), indicating that the observed olives output could be $34 \%$ higher with the same inputs levels.

Table 4. Technical Efficiencies statistics for olive trees, fruit trees, tomato and wheat

\begin{tabular}{lllll}
\hline \multirow{2}{*}{ Crop } & \multicolumn{4}{c}{ Technical Efficiencies (TE) } \\
\cline { 2 - 5 } & Olive & Fruit & Tomato & Wheat \\
\hline Mean & 0.66 & 0.86 & 0.86 & 0.85 \\
Min & 0.19 & 0.59 & 0.56 & 0.44 \\
Max & 1.00 & 1.00 & 1.00 & 1.00 \\
\hline
\end{tabular}

\subsection{Variability of Efficiency Scores}

The results of the variance analysis of the TE scores are summarized in Table 5. As mentioned in Section 2, the quantitative factor $\mathrm{E}_{\text {farm }}$ was transformed into 2 classes $\left(\mathrm{E}_{\text {farm }}<80 \%\right.$ and $\left.\mathrm{E}_{\text {farm }}>80 \%\right)$ where differences between the means were significant.

Results showed that the easy or difficult access to water is the only significant factor explaining differences of TE for olive trees, fruit trees and tomato, among farmers. Table 5 shows that the water supply to olive trees (easy or difficult) was a significant factor for TE $(p=0.032)$. In case of an easy access, TE was 0.74 but it was only 0.49 when there was a difficult access. 
Table 5. Results of the variance analysis: Mean Technical Efficiency (TE) for different sources of variation at the field level and $p$ values (The assumptions of the normally distribution with the same variance were full for all the sample)

\begin{tabular}{|c|c|c|c|}
\hline \multirow{2}{*}{ Sources of variation } & \multicolumn{3}{|c|}{ Technical Efficiency (TE) } \\
\hline & Olive trees & Fruit trees & Tomato \\
\hline Distribution sector & Not significant: NS & NS & NS \\
\hline Gravity & 0.69 & 0.88 & 0.87 \\
\hline Under pressure & 0.63 & 0.85 & 0.85 \\
\hline Irrigation technique (IT) & & $\mathrm{NS}$ & \\
\hline Surface $(\mathrm{Sr})$ & Only Sr was used & 0.82 & Only Tr was used \\
\hline Sprinkler (Sp) & (IT is not a source of variation) & - & (IT is not a source of variation) \\
\hline Trickle (Tr) & & 0.89 & \\
\hline Farm efficiency $\left(\mathrm{E}_{\text {farm }}\right)$ & $\mathrm{P}=0.032$ & $\mathrm{NS}$ & NS \\
\hline $\mathrm{E}_{\text {farm }}<80 \%$ & 0.53 & 0.9 & 0.93 \\
\hline $\mathrm{E}_{\text {farm }}>80 \%$ & 0.76 & 0.83 & 0.72 \\
\hline Water supply & $P=0.032$ & $P=0.023$ & $\mathrm{P}=0.020$ \\
\hline Easy access & 0.74 & 0.99 & 0.93 \\
\hline Difficult access & 0.49 & 0.81 & 0.72 \\
\hline
\end{tabular}

Neither the distribution sectors -gravity or under pressure- nor the irrigation technique was a significant factor for TE. This raised some questions about the utility of the gravity to pressure network conversion program and the incentives for installing trickle irrigation to save water. The efficiency of on-farm distribution to the field $\left(\mathrm{E}_{\text {farm }}\right)$ was a significant factor only for olive trees (Table 5). Although most of the wheat and winter crop fields were rain-fed, some received only one complement irrigation in which case the irrigation indicators were insignificant.

\section{Discussion}

In a context marked by the necessity of saving water and by questioning the performance of irrigation systems which have not attained their objectives, this research intends to develop a bechmark which can provide elements of response to these challenges, by analyzing the performance of irrigated fields in a transdisciplinary dimension. The bechmark used to analyse the performance at the field level allowed to define the real and relevant indicators for improvement. In addition to the state of the science, this study will enable decision-makers to know what should be acted on to improve performance, especially since the Tunisian government is preparing for a modernization project.

\subsection{Gravity Systems vs Pressurised Ones}

In Tunisia, a modernization plan was planned for the old irrigation schemes of the Medjerda Valley. The effective implementation of this plan started in 2010, and aimed at upgrading the gravity water distribution systems to the pressurised ones. Within this framework, results suggest that the type of distribution sector (gravity or pressurized) is not a significant factor affecting the TE of farmers. This later efficiency indicator is, however, significantly affected by the difficult or easy access to water, which is in line with other research findings stating that farmers become inefficient when their access to water is uncertain (Varghse, Veettil, Speelman, Buysse, \& Van Huylenbroeck, 2013). In this irrigation scheme, due to the low pressure at some points of the network, it will be easier to have a higher outflow on the Gravity distribution System (GS) compared to the Pressurized distribution System (PS). This constraint is an obstacle to the farmers located in the PS to reach better efficiencies. Although the GS suffers from other types of problems of upkeep and illegal water carrying, the PS also has his own shortcomings.It is indeed necessary to prioritize the modernization investments of the distribution networks based on relevant studies in order to maximize the social return and their impact on farmers. Paying attention to improving the access to water and controlling the illicit installation of water gates seems to be good and non-expensive options to enhance water management and irrigation performances in this study area.

\subsection{The Compromise Between Economic and Irrigation Performances}

Referring to the economic aspects, the majority of farms in our sample are actually producing at an efficient level despite the poor $\mathrm{E}_{\text {farm }}$ reflecting considerable water waste (Table 4). In a context characterized by low levels 
of intensification, water waste is not of great importance for farmers. There is a divergence between the farmer's interest (the economic efficiency) and the community's objective, which is to save water (better irrigation performance). The efforts of the government in providing incitation to farmers for better water use seem to be without results. In the context of this irrigation scheme, the water access and the reliability of water supply is a higher farming constraint compared to the irrigation efficiency.

\subsection{Lever for Improvement}

Our results show that irrigation performances do not correlate with economic performances at the field level. In this case study, the $\mathrm{E}_{\text {farm }}$ seems to be a very relevant irrigation indicator. The poor $\mathrm{E}_{\text {farm }}$ denotes a serious source of water loss. This goes against the important efforts made by the Tunisian government to invest in water saving technologies in irrigated agriculture. Previous studies have been conducted in Tunisia to evaluate the irrigation water use efficiency (IWUE) at different locations and with different crops. Frija, Chebil, Speelman, Buysse, \& Huylenbroeck (2009) found that IWUE was $42 \%$ in horticultural greenhouse, with pepper, tomato and melon, in the Eastern Central Tunisia. Dhehibi, Lachaal, Elloumi, and Messaoud (2007) evaluated IWUE in field scale for citrus production in Cap Bon (North East Tunisia) to 53\%. Albouchi, Bachta, and Jacquet (2005) showed that it was possible to improve water efficiency by $53 \%$ in the Kairouan region (Central Tunisia). All of these studies show that a great potential to save water and to enhance the performance of its use still exists in Tunisia.

Improving the access to water can lead to better economic conditions of the farmers but not to the best irrigation performance. The low $\mathrm{E}_{\text {farm }}$ is due to upgrated equipment in the majority of cases. However, the fact that the economic and irrigation performances are not related would make farmers unwilling to contribute to the on-farm improvement of the irrigatrion performances. The Tunisian National Irrigation Water Saving Program provides subsidies ranging from 40 to $60 \%$ to encourage farmers investing in new and modern irrigation equipment. Most farmers in this study area did not benefit from this subsidy program, due to many reasons (for example problems of land title). In this context, the improvement of irrigation efficiencies could be reached by further encouraging and assisting farmers' investments in adequate equipment and facilitating their access to the subsidy schemes offered for such type of investments. In line with this, the focus on irrigation pricing as a single (or dominant) irrigation management instrument can become a blocking factor and may lead to a decline of irrigated agriculture when it is associated with low levels of intensification (Pereira et al., 2011). Technical solutions combined within a set of appropriate intensification and water policy options might be a good alternative to stimulate sustainable use of irrigation water and creating positive socioeconomic dynamic at the local level. To this end, we recommend to further develop the capacities of local vulgarization services as well as farmer's knowledge by offering targeted trainings in relation to water productivity and intensification level.

\subsection{The Bechmark}

Our results justify the use of the bechmarking in building global representation adapted to the actual local context. This approach allowed understanding why irrigation performances are poor and determine the pertinent factors that may lead to their improvement. Such results might be useful for the development of the irrigation sector in Tunisia, especially in the current context of rehabilitation and modernization of the irrigation scheme. The approach outlined should be replicated in other irrigated areas to depict their context-specific levers of improvement. This study is a first step to define significant factors that contribute to enhancing the performance at field scale by bechmarking. Yet, in economic studies, the farm is seen as the relevant decision unit . Performance indicators should also be analyzed at farm level taken as a set of fields in interaction with each other and with other activities such as livestock.

\section{Conclusion}

The objective of this study was to depict effective and pertinent factors for a better management in the irrigated fields of a public irrigation scheme in Northern Tunisia. A benchmark was used to analyze the performance of irrigation systems at field scale. The relationship between irrigation and economic performance including other factors of the production process was investigated. For this, on-field irrigation measurements and monitoring events were processed to evaluate irrigation indicators on 31 individual fields. Then results of detailed techno-economic surveys on 91 fields were used to estimate the Technical Efficiencies (TE) for cultivated crops (olive trees, fruit trees, tomato and wheat). Finally, statistical variance analysis was used to evaluate a set of significant variables to depict effective and pertinent lever to better performance of irrigation systems. This study showed that irrigation performance, which has been widely studied with the aim of improving water management, does not always impact economic performance, which is the most important farmers' target. This is due to the irrigation water costs in comparison to the other input of the agricultural production in such low intensification context. In the context of the irrigation scheme support of this study, some farmers' 
strategies/practices are economically justified but may lead to a poor irrigation performance. Results showed that the on-farm distribution efficiency $\left(\mathrm{E}_{\text {farm }}\right)$ was the most pertinent irrigation indicator which was low ranging from $36 \%$ to $100 \%$, and causing considerable waste of water. With regard to economic aspects, the majority of farms are operating at an efficient level; the TE was around 0.85 for fruit trees, tomato and wheat and only 0.66 for olive trees. The statistical analysis showed that the access to water is the way for a better TE in the context of the studied area. However, the on-farm distribution efficiency $\left(\mathrm{E}_{\text {farm }}\right)$ is indeed not always significant for the TE, which is the ultimate and most important goal of the farmer. This is due to the fact that irrigation water costs are usually low compared to the other inputs in such a low intensification context. In the irrigated scheme considered for this case study, some farmers' strategies/practices are economically justified but may also lead to a poor irrigation performance.

Based on these results, to overcome this problem of the divergence of the community and the farmer's concerns, higher attention should be paid to the "water saving program" of Tunisia, by better targeting subsidies for irrigation investments and focusing on subsidies which are creating the most of economic growth and have an impact at the farm levels. Another major recommendation for policy makers is to increase the water cost in order to consider water as a production factor. The second suggestion would be to watch closely the illicit private pumping extensions in the irrigated areas of Tunisia.

\section{References}

Albouchi, L., Bachta, M. S., \& Jacquet, F. (2005). Estimation et décomposition de l'efficacité économique des zones irriguées pour mieux gérer les inefficacités existantes. Séminaire Euro Méditerrané: Les Instruments Economiques et la Modernisation des Périmètres Irrigués. Sousse, Tunisia.

Alene, A. D., \& Zeller, M. (2005). Technology adoption and farmer efficiency in multiple crops production in eastern Ethiopia: Acomparison of parametric and nonparametric distance functions. Agricultural Economics Review, 6(1), 5-17. https://doi.org/10.22004/ag.econ.44089

Bojanic, A. N., Caudil, S. B., \& Ford, J. M. (1998). Small sample properties of ML, COLS and DEA estimators of frontier models in the presence of heteroscedasticity. European Journal of Operational Research, 108(1), 140-148. https://doi.org/10.1016/S0377-2217(97)00101-X

Bravo-Ureta, B. E., \& Pinheiro, A. E. (1993). Efficiency Analysis of Developing Country Agriculture: A Review of the Frontier Function Literature. Agricultural and Resource Economics Review, 22(1), 88-101. https://doi.org/10.1017/S1068280500000320

Burt, C. M., \& Styles, S. W. (2004). Conceptualizing irrigation project modernization through benchmarking and the rapid appraisal process. Irrigation and Drainage, 53, 145-154. https://doi.org/10.1002/ird.127

Capone, R., Bilali, H., Elferchichi, A., Lamaddalena, N., \& Lamberti, L. (2012). Chapter 8. Natural resources and food in the Mediterranean. In Ciheam (Ed.), MediTERRA 2012: The mediterranean diet for sustainable regional development (pp. 171-193). https://doi.org/10.3917/scpo.chea.2012.02.0171

Chemak, F., Boussemart, J. P., \& Jacquet, F. (2010), Farming system performance and water use efficiency in the Tunisian semi-arid region: Data envelopment analysis approach. International Transactions in Operational Research, 17, 381-396. https://doi.org/10.1111/j.1475-3995.2009.00736.x

Coelli, T. (1996). A Guide to DEAP version 2.1: A Data Envelopment Analysis (Computer) Program. Centre for Efficiency and Productivity Analysis, Department of Econometrics, University of New England, Armidale, NSW, Australia.

Dhehibi, B., Lachaal, L., Elloumi, M., \& Messaoud, A. (2007). Measuring irrigation water use efficiency using stochastic production frontier: An application on citrus producing farms in Tunisia. African Journal of Agricultural and Resource Economics, 1(2), 99-114. https://doi.org/10.22004/ag.econ.57013

Dirwai, T. L., Senzanje, A., \& Mudhara, M. (2019). AN Investigation and condition assessment of the existing water control infrastructure in selected smallholder irrigation schemes: Case of Tugela ferry irrigation scheme and Mooi river irrigation scheme, South Africa. Irrigation and Drainage, 68(4), 657-668. https://doi.org/10.1002/ird.2347

Farrell, M. J. (1957). The measurement of productive efficiency. Journal of the Royal Statistical Society, 120(3), 253-290. https://doi.org/10.2307/2343100

Francis, M., Noble, A., Dennis, S., Rickerby, A., \& Knight, T. (2017). A graphical method to evaluate irrigation water application uniformity. New Zealand Journal of Agricultural Research, 60(1), 80-92. https://doi.org/ $10.1080 / 00288233.2016 .1267650$ 
Frija, A., Chebil, A., Speelman, S., Buysse, J., \& Huylenbroeck, G. V. (2009). Water use and technical efficiencies in horticultural greenhouses in Tunisia. Agricultural Water Management, 96(11), 1509-1516. https://doi.org/10.1016/j.agwat.2009.05.006

Ghazouani, W., Marlet, S., Mekki, I., \& Vidal, A. (2009). Farmer's perceptions and engineering approach in the modernazition of a community-managed irrigation scheme. A case study from an oasis of the Nefzawa (South of Tunisia). Irrigation and Drainage, 58(3), 285-296. https://doi.org/10.1002/ird.528

Goodstein, L., Nolan, T., \& Pfeiffer, J. W. (1993). Applied Strategic Planning: How to Develop a Plan that Really Works (2nd ed.). Pfeiffer, San Francisco, CA, USA.

Gorantiwar, S. D., \& Smout, I. K. (2005). Performance assessment of irrigation water management of heterogeneous irrigation schemes: 1. A framework for evaluation. Irrigation and Drainage Systems, 19, 1-36. https://doi.org/10.1007/s10795-005-2970-9

Hamdi, A., Ragab, R., \& Scarascia-Mugnozza, E. (2003). Coping with water scarcity: Water saving and increasing water productivity. Irrigation and Drainage, 52, 3-20. https://doi.org/10.1002/ird.73

Horst, M. G., Shamutalov, S. S., Pereira, L. S., \& Gonçalves, J. M. (2005). Field assessment of the water saving potential with furrow irrigation in Fergana, Aral Sea basin. Agricultural Water Management, 77(1-3), 210-231. https://doi.org/10.1016/j.agwat.2004.09.041

Hsiao, T. C., Steduto, P., \& Fereres, E. (2007). A systematic and quantitative approach to improve water use efficiency in agriculture. Irrigation Science, 25, 209-231. https://doi.org/10.1007/s00271-007-0063-2.

Jamasb, T., \& Pollitt, M. (2001). Benchmarking and regulation: International electricity experience. Utilities Policy, 9(3), 107-130. https://doi.org/10.1016/S0957-1787(01)00010-8

Juana, L., Rodriguez-Sinobas, L., Sànchez, R., \& Losada, A. (2007). Evaluation of drip irrigation: Selection of emitters and hydraulic characterization of trapezoidal units. Agricultural Water Management, 90(1-2), 13-26. https://doi.org/10.1016/j.agwat.2007.01.007

Le Grusse, P., Mailhol, J. C., Bouaziz, A., Zairi, A., Raki, M., Chabaka, M., ... Ruelle, P. (2009). Indicators and framework for analysing the technical and economic performance of irrigation systems at farm level. Irrigation and Drainage, 58(3), 307-319. https://doi.org/10.1002/ird.532

Lorite, I. J., Mateo, L., \& Fereres, E. (2004). Evaluating irrigation performance in a Mediterranean environment. II. Variability among crops and farmers. Irrigation Science, 23, 85-92. https://oi.org/10.1007/ s00271-004-0096-8

Mailhol, J. C., Zairi, A., Slatni, A., Ben Nouna, B., \& El Amami, H. (2004). Analysis of irrigation systems and irrigation strategies for durum wheat in Tunisia. Agricultural water Management, 70(1), 19-37. https://doi.org/10.1016/j.agwat.2004.06.001

Malano, H., Burton, M., \& Makin, I. (2004). Benchmarking performance in the irrigation and drainage sector: A tool for change. Irrigation and Drainage Systems, 53(2), 119-133. https://doi.org/10.1002/ird.126.

Merrey, D., \& Sally, H. (2008). Micro-agricultural water management technologies for food security in Southern Africa: Part of the solution or a red herring? Water Policy, 10, 515-530. https://doi.org/10.2166/ wp. 2008.025

Miao, Q., Shi, H., Gonçalves, J. M., \& Pereira, L. S. (2015). Field assessment of basin irrigation performance and water saving in Hetao, Yellow River basin: Issues to support irrigation systems modernisation. Biosystems Engineering, 136, 102-116. https://doi.org/10.1016/j.biosystemseng.2015.05.010

Molden, D. J., \& Sakthivadivel, R. (1999). Water accounting to assess use and productivity of water. Water Resources Development, 15, 55-71. https://doi.org/10.1080/07900629948934

Nyemeck, J. B., \& Nkamleu, G. B. (2006). Potentiel de Productivité et Efficience Technique du Secteur Agricole en Afrique. Canadian Journal of Agricultural Economics/Revue canadienne d'agroeconomie, 54, $361-377$. https://doi.org/10.1111/j.1744-7976.2006.00055.x

Pereira, L. S. (1999). Higher performances through combined improvements in irrigation methods and scheduling: A discussion. Agricultural Water Management, 40(2-3), 153-169. https://doi.org/10.1016/ S0378-3774(98)00118-8 
Pereira, L. S., Cordery, I., \& Iacovides, I. (2011). Improved indicators of water use performance and productivity for sustainable water conservation and saving. Agricultural Water Management, 108, 39-51. https://doi.org/ 10.1016/j.agwat.2011.08.022

Pereira, L. S., Goncalves, J. M., Dong, B., Mao, Z., \& Fang, S. X. (2007). Assessing basin irrigation and scheduling strategies for saving irrigation water and controlling salinity in the upper Yellow River Basin, China. Agricultural Water Management, 93(3), 109-122. https://doi.org/10.1016/j.agwat.2007.07.004

Pereira, L. S., Oweis, T., \& Zairi, A. (2002). Irrigation management under water scarcity. Agricultural Water Management, 57, 175-206. https://doi.org/10.1016/S0378-3774(02)00075-6

Rodriguez-Diaz, J. A., Camacho, P. E., \& Lopez Luque, R. (2004). Application of data envelopment analysis tostudies of irrigation efficiency in Andalusia. Journal of Irrigation and Drainage, 130(3), 175-183. https://doi.org/10.1061/(ASCE)0733-9437(2004)130:3(175)

Sinuany-Stern, Z., Mehrez, A., \& Hadad, Y. (2000). An AHP/DEA methodology for ranking decision making units. International Transactions in Operational Research, 7(2), 109-124. https://doi.org/10.1111/ j.1475-3995.2000.tb00189.x

Slatni, A., Zayani, K., Zairi, A., Yacoubi, S. Salvador, R., \& Playan, E. (2011). Assessing alternate furrow strategies for potato at the Cherfech irrigation district of Tunisia. Biosystems Engineering, 108(2), 154-163. https://doi.org/10.1016/j.biosystemseng.2010.11.008

Thanassoulis, E. (2000). The use of data envelopment analysis in the regulation of UK water utilities: Water distribution. European Journal of Operational Research, 126(2), 436-453. https://oi.org/10.1016/ S0377-2217(99)00303-3

Thiam, A., Bravo-Ureta, B. E., \& Rivas, T. E. (2001). Technical Efficiency in Developing Country Agriculture a Meta-analysis. Agricultural Economics, 25(2-3), 235-243. https://doi.org/10.1111/j.1574-0862.2001. tb00204.x

Tongzon, J. (2001). Efficiency measurement of selected Australian and other international ports using data envelopment analysis. Transportation Research Part A: Policy and Practice, 35(2), $107-122$. https://doi.org/10.1016/S0965-8564(99)00049-X

Vandersypen, K., Bengaly, K., Keita, A. C. T., Sidibe, S., Raes, D., \& Jamin, J. Y. (2006). Irrigation performance at tertiary level in the rice schemes of the Office of Niger: Adequate water delivery through over-supply. Agricultural Water Management, 83(1-2), 144-152. https://doi.org/10.1016/j.agwat.2005.11.003

Varghse, S. K., Veettil, P. C., Speelman, S., Buysse, J., \& Van Huylenbroeck, G. (2013). Estimating the causal effect of water scarcity on the groundwater use efficiency of rice farming in South India. Ecological Economics, 86, 55-64. https://doi.org/10.1016/j.ecolecon.2012.10.005

Wadud, A., \& White, B. (2000). Farm household efficiency in Bangladesh: A comparison of stochastic frontier and DEA methods. Applied Economics, 32(13), 1665-1673. https://doi.org/10.1080/000368400421011

Yacoubi, S., Zayani, K., Zapata, N., Zairi, A., Slatni, A., Salvador, R., \& Palayan, E. (2010). Day and night time sprinkler irrigated tomato: Irrigation performance and crop yield. Biosystems Engineering, 107(1), 25-35. https://doi.org/10.1016/j.biosystemseng.2010.06.009

Zairi, A., El Amami, H., Slatni, A., Pereira, L. S., Rodrigues, P. N., \& Machado, T. (2003). Coping with drought: deficit irrigation strategies for cereals and field horticultural crops in Central Tunisia. In G. Rossi, A. Cancelliere, L. S. Pereira, T. Oweis, M. Shatanawi, \& A. Zairi (Eds.), Tools for Drought Mitigation in Mediterranean Regions (pp. 181-201). Kluwer, Dordrecht. https://doi.org/10.1007/978-94-010-0129-8_11

Zoebl, D. (2006). Is water productivity a useful concept in agricultural water management? Agricultural Water Management, 84(3), 265-273. https://doi.org/10.1016/j.agwat.2006.03.002

\section{Copyrights}

Copyright for this article is retained by the author(s), with first publication rights granted to the journal.

This is an open-access article distributed under the terms and conditions of the Creative Commons Attribution license (http://creativecommons.org/licenses/by/4.0/). 